\title{
Effect of vaginal pH on efficacy of dinoprostone gel for labour induction
}

\author{
Maria Joseph Kurian*, Bharathi Rao, Arun Rao, Shameem V. P. A.
}

Department of Obstetrics and Gynecology, Kasturba Medical College, Manipal University, Manipal, India

Received: 16 February 2016

Accepted: 12 March 2016

*Correspondence:

Dr. Maria Joseph Kurian,

E-mail: mjk1085@gmail.com

Copyright: (c) the author(s), publisher and licensee Medip Academy. This is an open-access article distributed under the terms of the Creative Commons Attribution Non-Commercial License, which permits unrestricted non-commercial use, distribution, and reproduction in any medium, provided the original work is properly cited.

\begin{abstract}
Background: Induction of labour is defined as an intervention designed to artificially initiate uterine contractions leading to progressive dilatation and effacement of the cervix and birth of the baby. The aim of the study was to evaluate the influence of vaginal $\mathrm{pH}$ on the efficacy of dinoprostone gel for labor induction.

Methods: A prospective study conducted on 200 subjects within 1 year in India. The Bishop score and vaginal $\mathrm{pH}$ (with $\mathrm{pH}$ paper, Sigma Chemical Company, St. Louis, USA) of subjects undergoing induction of labor with dinoprostone gel was assessed prior induction. After 6 hours of induction, PGE2 gel was repeated or labor was augmented. The vaginal $\mathrm{pH}$ measured was compared with age, parity, Bishop Score, time to enter into active phase of labor, and the mode of delivery. The significance of association was calculated by Chi-square test.

Results: Majority subjects had $\mathrm{pH}$ in the range 5-6.Subjects with higher parity were associated with higher vaginal ph. Higher vaginal $\mathrm{pH}$ was associated with a higher Bishop score prior to induction, responded to single induction, and had a higher number of vaginal deliveries than those with lower vaginal $\mathrm{pH}$. There was no significant association found in vaginal $\mathrm{pH}$ and the time taken to enter into active phase of labor. Subjects with pregnancy induced hypertension were found to have higher vaginal ph.

Conclusions: Parity influences vaginal $\mathrm{pH}$ and vaginal $\mathrm{pH}$ itself has a significant effect on the Bishop Score prior induction. Hence knowing the vaginal $\mathrm{pH}$ prior induction could be a useful tool to assess the labor outcome in induction with $\mathrm{PGE}_{2}$.
\end{abstract}

Keywords: Vaginal pH, Labour induction, Dinoprostone gel $\left(\mathrm{PGE}_{2}\right)$

\section{INTRODUCTION}

Induction of labour is defined as an intervention designed to artificially initiate uterine contractions leading to progressive dilatation and effacement of the cervix and birth of the baby. About $20 \%$ of pregnant women will have labour induced for a variety of reasons. There are various medical and surgical methods of Induction/Cervical ripening. Overall, induction of labour using prostaglandins seem to improve the rate of successful vaginal delivery, lower the rate of caesarean section, lower epidural usage and to be associated with improved maternal satisfaction. ${ }^{1}$
Cervical ripening is the process that culminates in the softening and distensibility of the cervix, which facilitates labor and delivery. The cervix contains relatively few smooth muscle cells and derives its rigidity from collagen bundles surrounded by proteoglycans. In pregnancy nearing term, there are various factors that induce certain changes in the cervix leading to cervical ripening. There are agents that can artificially induce these changes if it has not occurred. It is difficult to separate methods of cervical ripening and labor induction. ${ }^{4}$

Cervical ripening is associated with the disorganization of collagen bundles which is likely to be effected by collagenase. The active area of cervical tissue remodelling is at the internal OS. The collagenase found in the cervix has been identified as neutrophil derived and 
the invading neutrophil plays an important role in the tissue rearrangements associated with cervical ripening. Neutrophils represent a readily available source of collagenase, present in specific granules, which can be made available by degranulation by a variety of cytokines including interleukin (IL-8). This dual action of IL-8, recruiting and exciting neutrophils, makes it a powerful agent in initiating rearrangement of extracellular matrix. $^{2,3}$

Prostaglandin (PGE) is a well-established agent that has a primary action in softening the cervix. Compounds such as IL-8 act synergistically with PGE in attracting neutrophils. ${ }^{2}$

The human uterine cervix can produce nitric oxide (NO), a free radical with an ultra-short half-life. Nitric oxide in the human uterine cervix acts as an endogenous ripening factor with an unknown mechanism of action. In two studies conducted by Vaisanen-Tommiska $\mathrm{M}$ et al, it was found that cervical fluid nitric oxide metabolite level rises after cervical ripening, nitric oxide donor administration, or cervical manipulation, which supports a role for cervical nitric oxide in cervical ripening.,

Nitric oxide and PGE are the two pathways that, cross activating each other, trigger the cascade of events responsible of cervical ripening.

M. Norman et al studied the metabolism of cervical connective tissue in cervical biopsies from non-pregnant and pregnant cases. The concentration of proteoglycans in the pregnant cervix was found to be approximately one-half of that in the non-pregnant cervix indicating that the turnover of proteoglycans in pregnant cervical tissue was significantly increased. After prostaglandin induction it was found that the decrease in sulfated glycosaminoglycans could decrease electrostatic interactions that would weaken interfibrillar interactions that would be consistent with a decline in cervical resistance. The involvement of matrix metalloproteinases (MMP) i.e. MMP-2 and MMP-9 in the cervical ripening process has been indicated in cervical ripening.

To summarize, the complex interactions of various cytokines bring about profound changes in the proteoglycans in the cervix which eventually leads to cervical ripening.

Recently, vaginal $\mathrm{pH}$ has been investigated as a potential factor influencing the efficacy of prostaglandins for cervical ripening and labor induction but the results have been conflicting. Studies have been conducted on the effects of vaginal $\mathrm{pH}$ on the efficacy of controlled-release $\mathrm{PGE}_{2}$ vaginal insert and $\mathrm{PGE}_{2}$ gel for cervical priming/labor induction in which overall vaginal $\mathrm{pH}$ seemed to influence the $\mathrm{PGE}_{2}$ release. ${ }^{9-11}$
Nonetheless, the effect of vaginal $\mathrm{pH}$ on overall efficacy of the cervical ripening/labor induction with $\mathrm{PGE}_{2}$ has not been well studied.

The vaginal $\mathrm{pH}$ in pregnancy is known to be acidic and not much is known about the variations in vaginal $\mathrm{pH}$ throughout pregnancy. There are studies that mention that $\mathrm{pH}$ may change the degree of ionization of a drug and affect the absorption of the drug resulting in variable clinical responses. $^{13,16}$

Vaginal $\mathrm{pH}$ changes also has a role in preterm delivery which suggests that it has a role in influencing cervical ripening. ${ }^{14,15}$

The purpose of this study is to evaluate the influence of vaginal $\mathrm{pH}$ on the efficacy of $\mathrm{PGE}_{2}$ gel for cervical ripening/labour induction which would improve patient selection for $\mathrm{PGE}_{2}$ induction and reduce the incidence of failed induction with $\mathrm{PGE}_{2}$.

\section{METHODS}

A prospective study was conducted on 200 subjects who were undergoing induction of labour with dinoprostone (PGE2) gel. All subjects had a medical or an obstetric indication for induction of labour. The study was conducted for a duration of 1 year at Lady Goschen Hospital, Mangalore,Karnataka,India approved by the ethics committee.

Inclusion criteria were: Unfavourable cervix, Singleton pregnancy with vertex presentation and no contraindication to vaginal delivery, Absence of spontaneous uterine contractions, Reactive NST.

Exclusion criteria included: Hypersensitivity to prostaglandins, Ruptured membranes, Chorioamnionitis, Previous LSCS.

Subjects who met the above mentioned criterias were enrolled in this study after giving an informed consent.

1. The vaginal $\mathrm{pH}$ of the subjects was assessed with $\mathrm{pH}$ indicator paper strips ( $\mathrm{pH}$ paper, Sigma Chemical Company, St. Louis, USA) after performing cardiotocography to rule out uterine contractions and to assess fetal status.

2. Bishop score was assessed: Cervical dilatation, cervical effacement/length, Cervical consistency, Cervical position, Fetal station. Each component is given a score of $0-2$ or $0-3$. The highest possible score is 13 and $<5$ is unfavourable that needs induction. $^{1}$

3. All received intracervically placed PGE2 gel $0.5 \mathrm{mg}$. After 6 hrs depending on Bishop Score and uterine contraction either PGE2 gel was repeated (maximum 3 doses) or labour was augmented as per labour theatre protocol. ${ }^{1}$ The time taken to enter into active phase of labour was assessed. 
4. The subjects were divided into two groups one with higher vaginal $\mathrm{pH}$ and the other with lower vaginal $\mathrm{pH}$ and the differences between the groups with respect to age, parity, Bishop score prior induction, need for a second induction, time to enter into active phase of labour and the final mode of delivery were compared and analysed.

A statistical package SPSS version 17.0 was used to do the analysis. The significance of association of each was calculated by Chi-square test. $\mathrm{P}$ value $<0.05$ was considered significant.

\section{RESULTS}

Table 1: Comparison of vaginal pH and age.

\begin{tabular}{|lll|}
\hline $\mathrm{pH}$ & Age $<25$ year $\mathrm{n}=\%$ & Age $>=25$ years $\mathrm{n}=\%$ \\
\hline$<=4$ & 92.9 & 7.1 \\
\hline 4.5 & 83.3 & 16.7 \\
\hline 5 & 97.1 & 2.9 \\
\hline 5.5 & 88.7 & 11.3 \\
\hline$>=6$ & 82.1 & 17.9 \\
\hline
\end{tabular}

Data as $\mathrm{n}=\%$; $* \mathrm{P}$ value $=0.208$

Table 2: Comparison of vaginal $\mathrm{pH}$ and time taken to enter active phase of labour.

\begin{tabular}{|lll|}
\hline pH & $\begin{array}{l}\text { Time taken to } \\
\text { enter active } \\
\text { phase }<12 \\
\text { hours } \quad \text { n=\% }\end{array}$ & $\begin{array}{l}\text { Time taken to } \\
\text { enter active } \\
\text { phase }>=12 \\
\text { hours } \quad \mathrm{n}=\%\end{array}$ \\
\hline$<=4$ & 83.3 & 16.7 \\
\hline 4.5 & 57.1 & 42.9 \\
\hline 5 & 66.7 & 33.3 \\
\hline 5.5 & 70.8 & 29.2 \\
\hline$>=6$ & 85.5 & 14.5 \\
\hline
\end{tabular}

Data as $\mathrm{n}=\%$; $* \mathrm{P}$ value $=0.099$

Table 3: Comparison of vaginal $\mathrm{pH}$ and various indications of LSCS.

\begin{tabular}{|llllll|}
\hline pH & $\begin{array}{l}\text { Failed } \\
\text { induction } \\
\mathrm{n}=\%\end{array}$ & $\begin{array}{l}\text { Arrest of descent } \\
\mathrm{n}=\%\end{array}$ & $\begin{array}{l}\text { Non } \\
\text { reassuring } \\
\text { foetal } \\
\text { status } \\
\mathrm{n}=\%\end{array}$ \\
\hline$<=4$ & 62.5 & 4.2 & 33.3 & & \\
\hline 4.5 & 14.2 & & 0 & 85.8 & \\
\hline 5 & 11.2 & & & 33.3 & 55.5 \\
\hline 5.5 & 12.5 & & & 50 & 37.5 \\
\hline$>=6$ & 37.5 & & & 12.5 & 50 \\
\hline
\end{tabular}

Data as $\mathrm{n}=\%$; $* \mathrm{P}$ value $=0.000$

In this observational study, 200 subjects who were induced with prostaglandin gel were taken randomly. Vaginal $\mathrm{pH}$ was measured and compared with respective age, parity, Bishop Score prior induction, need for a repeat induction, time to enter active phase and the final mode of delivery.

Majority of the study subjects had $\mathrm{pH}$ in the range of 5-6 (Figure 1).

The vaginal $\mathrm{pH}$ in pregnancy is known to be acidic and not much is known about the variations in vaginal $\mathrm{pH}$ throughout pregnancy. In the present study most of the subjects were found to have $\mathrm{pH}$ between 5-6.

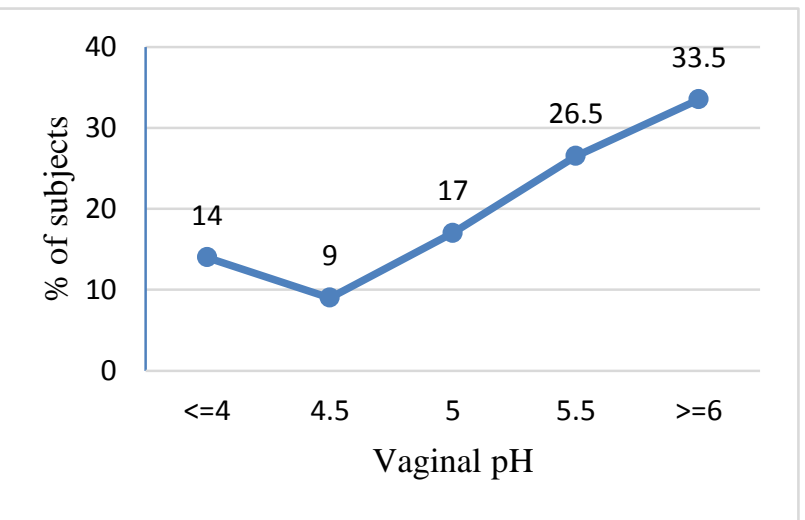

Figure 1: Vaginal pH among the study subjects. Majority of the study subjects had $\mathrm{pH}$ in the range of 5-6.

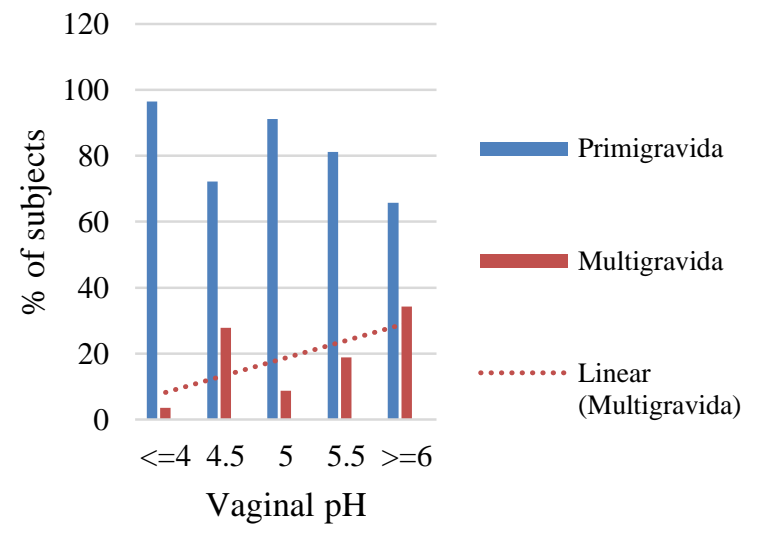

Figure 2: Comparison of vaginal $\mathrm{pH}$ with parity.

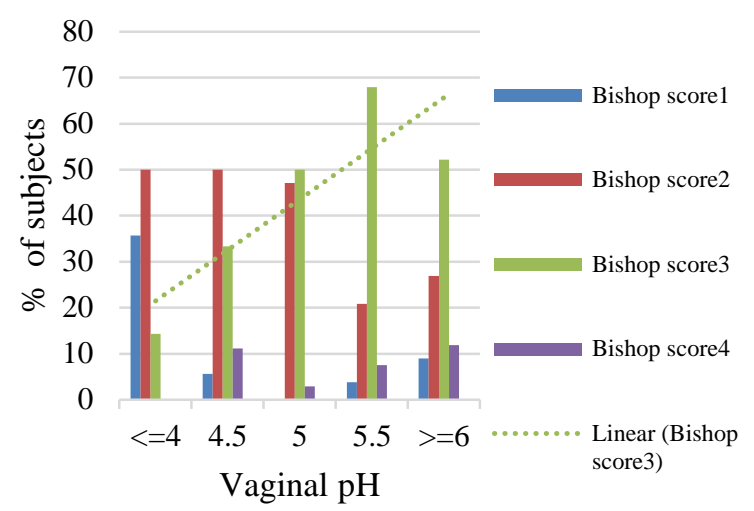

Figure 3: Comparison of vaginal $\mathrm{pH}$ and Bishop Score 
There was no significant association found between vaginal $\mathrm{pH}$ and age of the subjects (Table 1). Although there was a significant association between vaginal $\mathrm{pH}$ and parity. Subjects of a higher parity had a higher vaginal $\mathrm{pH}(>=5)$ as depicted by the dotted lines which was statistically significant $(\mathrm{P}=0.003)$ (Figure 2).

Subjects with a higher vaginal $\mathrm{pH} \quad(>=5)$ had higher Bishop Score $(3,4)$ as depicted by the dotted line which was statistically significant $(\mathrm{P}=0.000)$ (Figure 3).

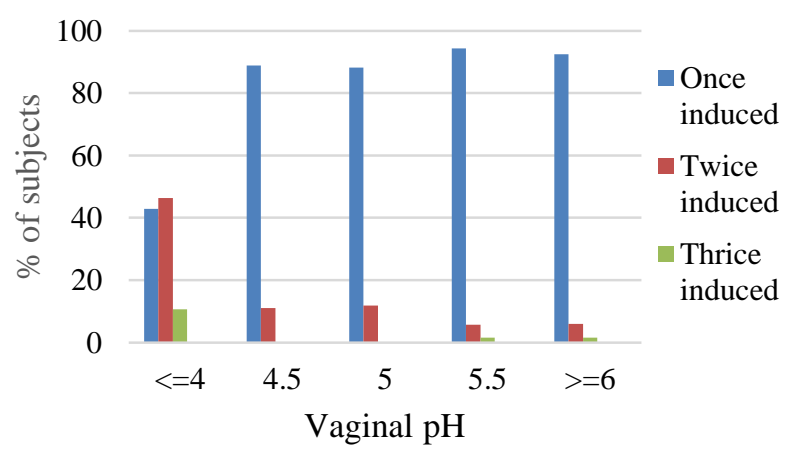

Figure 4: Comparison of vaginal $\mathrm{pH}$ and the number of times a subject was induced.

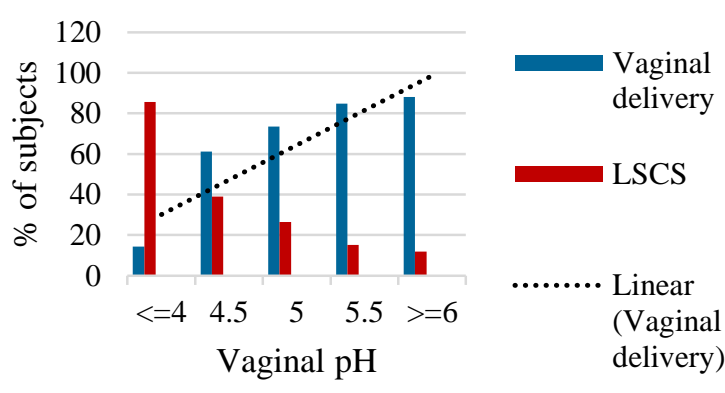

Figure 5: Graphical representation of vaginal $\mathrm{pH}$ and the delivery outcome.

Subjects with a higher vaginal $\mathrm{pH}(>=5)$ responded to a single induction while subjects with lower vaginal $\mathrm{pH}$ needed a repeat induction (maximum of three doses in an interval of 6 hours) which was statistically significant $(\mathrm{P}=0.000)$ (Figure 4).

There was no significant association found in vaginal $\mathrm{pH}$ influencing the time taken to enter active phase of labor (Table 2).

Subjects with higher vaginal $\mathrm{pH}(>=5)$ was associated with more number of vaginal deliveries and subjects with lower vaginal $\mathrm{pH}$ was associated with more number of LSCS as depicted by the dotted lines which was statistically significant $(\mathrm{P}=0.000)$ (Figure 5).

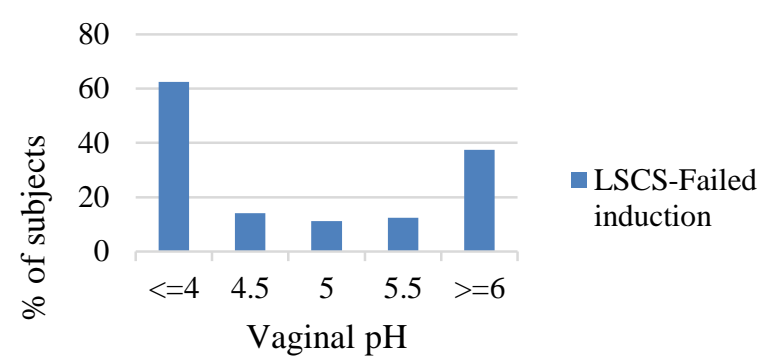

Figure 6: The number of subjects who went for LSCS with failed induction as the indication of LSCS.

Most of the subjects who underwent LSCS for failed induction being the indication for LSCS had a lower vaginal $\mathrm{pH}$ (Table 3/Figure 6).

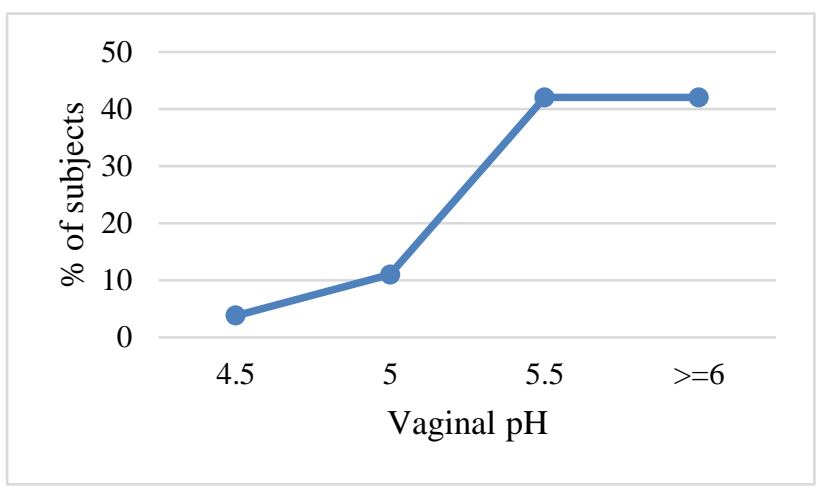

Figure 7: Graphical representation of comparison of vaginal $\mathrm{pH}$ in subjects with pregnancy induced hypertension.

Subjects with pregnancy induced hypertension were found to have higher vaginal $\mathrm{pH}$ (Figure 7).

\section{DISCUSSION}

Among the previous studies in the literature; there are three studies investigating the effect of vaginal $\mathrm{pH}$ on efficacy of PGE2 gel and the another three investigating the effect of vaginal $\mathrm{pH}$ on the efficacy of slow-release PGE2 vaginal insert in vivo but giving conflicting results. $^{8-11,17,18}$

The first study was carried out in 2001 by Lyrenas et al, who evaluated the effect of vaginal $\mathrm{pH}$ and efficacy of a controlled-release $\mathrm{PGE}_{2}$ vaginal insert in 68 subjects with an unfavourable cervix who were undergoing labor induction and the investigators noted a significant correlation between vaginal $\mathrm{pH}$ and $\mathrm{PGE}_{2}$ release from the insert. ${ }^{10}$

Ramsey et al studies conducted in 2002 and 2003 conflict each other. ${ }^{8,9}$ The study in 2002 conducted with $\mathrm{PGE}_{2}$ gel showed significant association between higher vaginal $\mathrm{pH}$ and the shorter time taken to enter into active phase, time to full dilatation and time to delivery while the study in 2003 conducted with $\mathrm{PGE}_{2}$ vaginal insert showed no 
significance. The present study also showed no significant change in the time to enter active phase of labor.

In the present study conducted there was a significant association found between the vaginal $\mathrm{pH}$ and the Bishop score prior induction but the change in the Bishop score over 6-8 hours of induction could not be assessed. In the studies conducted by Ramsey et al and Basirat et al, there was no significant association found between vaginal $\mathrm{pH}$ and the initial Bishop score prior induction and the change in the Bishop score over 12 hours in contrast to the study conducted by Singh u et al where there was significant association found between the vaginal $\mathrm{pH}$ and the change in the Bishop score over 18 hours which may be due to the difference in the duration (in hours) of assessment of Bishop score after an induction.

Table 4: Summary of comparison of the present study with previous conducted studies.

\begin{tabular}{|c|c|c|c|c|c|c|c|}
\hline $\begin{array}{l}\text { Year } \\
\text { of } \\
\text { study }\end{array}$ & $\begin{array}{l}\text { Study } \\
\text { conducted by }\end{array}$ & $\begin{array}{l}\text { PGE2 } \\
\text { form } \\
\text { used in } \\
\text { study }\end{array}$ & $\begin{array}{l}\text { Number } \\
\text { of } \\
\text { subjects } \\
\text { in study }\end{array}$ & $\begin{array}{l}\text { Association of } \\
\text { vaginal pH } \\
\text { and } A G E\end{array}$ & $\begin{array}{l}\text { Association of } \\
\text { vaginal pH } \\
\text { and PARITY }\end{array}$ & $\begin{array}{l}\text { Association of } \\
\text { vaginal pH and } \\
\text { Bishop score } \\
\text { prior induction }\end{array}$ & $\begin{array}{l}\text { Association } \\
\text { of vaginal } \\
\text { pH and time } \\
\text { to enter } \\
\text { active phase }\end{array}$ \\
\hline 2002 & Ramsey et al & Gel & 32 & $\mathrm{a}$ & $\mathrm{a}$ & $\mathrm{a}$ & $\mathrm{b}$ \\
\hline 2003 & Ramsey et al & Insert & 34 & $\mathrm{a}$ & $\mathrm{a}$ & $\mathrm{a}$ & $\mathrm{a}$ \\
\hline 2008 & Onen et al & Insert & 63 & $\mathrm{a}$ & $\mathrm{a}$ & $\mathrm{a}$ & $\mathrm{a}$ \\
\hline 2011 & Singh U et al & Gel & 45 & $\mathrm{a}$ & $\mathrm{a}$ & $\mathrm{a}$ & $\mathrm{a}$ \\
\hline \multirow[t]{2}{*}{2012} & Basirat et al & Gel & 147 & $\mathrm{a}$ & $\mathrm{a}$ & $\mathrm{a}$ & $\mathrm{b}$ \\
\hline & Present study & Gel & 200 & $\mathrm{a}$ & $\mathrm{b}$ & $\mathrm{b}$ & $\mathrm{a}$ \\
\hline
\end{tabular}

a- Significant association; b- No significant association

Basirat et al also found that the incidence of Cesarean section was lower in women with high vaginal $\mathrm{pH}$ as in the present study but was not statistically significant.

Vaginal pH has been investigated in several recent studies as a factor that may account for the variability observed clinically with prostaglandin used as cervical ripening/labor induction agents. Two in vitro studies by Johnson et al. and MacDonald and Weir describes an increased $\mathrm{PGE}_{2}$ release in solutions with a higher $\mathrm{pH}$. (6.5 to 7.5) It was also reported in the two in vitro studies that along with the increased release of $\mathrm{PGE}_{2}$, it is also predominantly ionized at a $\mathrm{pH}$ of $7.5(\mathrm{pKa}, 4.9)$, which diminishes the potential of its systemic absorption. ${ }^{13,16}$

Lyrenas et al further noted that high vaginal $\mathrm{pH}$ (6.5-7.5) and therefore increased $\mathrm{PGE}_{2}$ release did not equate to increased plasma concentrations of $\mathrm{PGE}_{2}$ and its metabolites. Therefore, why vaginal $\mathrm{pH}$ affected the cervical priming but did not affect the labor outcomes in present study may be due to these findings that ionization of $\mathrm{PGE}_{2}$ in high $\mathrm{pH}$ might cause local effects, like change in Bishop's score, and the diminishing of its absorption may decrease its systemic effects and therefore, absence of change in labor outcome. ${ }^{11}$

An important observation made in the present study was that subjects with pregnancy induced hypertension were found to have a higher vaginal $\mathrm{pH}$ (Figure 7). Hence this observation could probably explain on why subjects with pregnancy induced hypertension respond well to $\mathrm{PGE}_{2}$ induction and further studies are required to substantiate its significance.

The $\mathrm{pH}$ is important in terms of the design and the efficacy of vaginal drug delivery systems. The effect of vaginal $\mathrm{pH}$ on the efficacy of sustained-release PGE vaginal insert could be better established if the vaginal insert had been moistened with solutions having different $\mathrm{pH}$ as in the previous studies. ${ }^{19}$

\section{CONCLUSION}

Hence, findings of the present study suggest that parity influences vaginal $\mathrm{pH}$ and vaginal $\mathrm{pH}$ itself has a significant effect on cervical ripening and the Bishop Score prior induction. Higher vaginal $\mathrm{pH}$ more often responds to a single induction and is more often associated with vaginal deliveries than LSCS.

Hence knowing the vaginal $\mathrm{pH}$ prior induction could prove to be a useful tool in assessing the labor outcome of a patient undergoing labor induction with PGE2 gel. Further research is required to find various agents that would increase the vaginal $\mathrm{pH}$ thereby creating a favorable environment for PGE2 gel induction.

\section{Funding: Not required}

Conflict of interest: None declared

Ethical approval: The study was approved by the Institutional Ethics Committee 


\section{REFERENCES}

1. RCOG. Royal College of Obstetricians and Gynaecologists. Induction of labour. 2008;1:1$12,5: 45-68$

2. Kelly RW. Inflammatory mediators and parturition. Reviews of Reproduction. 1996;1:89-96.

3. Denison FC, Calder AA, Kelly RW. The action of prostaglandin E2 on the human cervix: stimulation of interleukin 8 and inhibition of secretory leukocyte protease inhibitor. Am J Obstet Gynecol. 1999;180(3 Pt. 1):614-20.

4. Sanchez-Ramos L. Induction of Labor. Obstet Gynecol Clin N Am. 2005;32:181-200.

5. Vaisanen-Tommiska M, Nuutila M, Aittomaki K, Hiilesmaa V, Ylikorkala O. Nitric oxide metabolites in cervical fluid during pregnancy: further evidence for the role of cervical nitric oxide in cervical ripening. Am J Obstet Gynecol. 2003;188(3):779-85.

6. Norman M, Ekman G, Ulmsten U, Barchan K Malmstrom A. Proteoglycan metabolism in the connective tissue of pregnant and non-pregnant human cervix. An in vitro study. Biochem. J. 1991;275:515-20.

7. Marx SG. Effects of Progesterone on iNOS, COX-2, and Collagen Expression in the Cervix. Journal of Histochemistry \& Cytochemistry. 2006;54(6):62339.

8. Ramsey PS, Ogburn PL Jr, Harris DY, Heise RH, Ramin KD. Effect of vaginal $\mathrm{pH}$ on efficacy of the dinoprostone gel for cervical ripening/labor induction.AmJObstet Gynecol. 2002;187:843-6.

9. Ramsey PS, Ogburn PL Jr, Harris DY et al. Effect of vaginal $\mathrm{pH}$ on efficacy of the controlled-release dinoprostone vaginal insert for cervical ripening/labor induction. J Matern Fetal Neonatal Med. 2003;13:250-3.

10. Lyrenas S, Clason I, Ulmsten U. In vivo controlled release of PGE2 from a vaginal insert $(0.8 \mathrm{~mm}, 10$ $\mathrm{mg}$ ) during induction of labor. Br J Obstet Gynaecol. 2001;108:169-78.
11. Onen fi, Ozakflit G, Yilmaz B. The Role of Vaginal pH on Efficacy of Controlled-Release Dinoprostone Vaginal Insert for Cervical Ripening/Labor Induction: A Prospective Double-Blind Study.J Turkish-German Gynecol Assoc. 2008;9(4):206-11.

12. Calder AA, Brennand JE. Labor and normal delivery: Induction of labor. Curr Opin Obstet Gynecol. 1991;3:764.

13. Johnson TA, Greer IA, Kelly RW, Calder AA. The effect of $\mathrm{pH}$ on the release of PGE2 from vaginal and endocervical preparations for induction of labour:an in-vitro study. Br J Obstet Gynaecol. 1992;99:87780.

14. Hauth JC. Early pregnancy threshold vaginal $\mathrm{pH}$ and Gram stain scores predictive of subsequent preterm birth in asymptomatic women. Am J Obstet Gynecol. 2003;188(3):831-5.

15. Gleeson RP, Elder AM, Turner MJ, Rutherford AJ, Elder MG. Vaginal pH in pregnancy in women delivered at and before term. Br J Obstet Gynaecol. 1989;96(2):183-7.

16. MacDonald IA, Weir RF. The effect of $\mathrm{pH}$ on release of PGE2 from vaginal and endocervical preparations for induction of labour.Br $\mathrm{J}$ Obstet Gynaecol. 1993;100:1066-7.

17. Singh U, Mehrotra S, Gupta HP, Dhakad A, Jain V. A prospective double blind trial investigating impact of vaginal $\mathrm{pH}$ on efficacy of prostaglandin gel for cervical ripening and course of labour.J Obstet Gynaecol. 2011;31(3):217-9.

18. Basirat Z, Barat SH, Ghanbarpour A, GolsorkhtabarAmiri M. Does vaginal $\mathrm{pH}$ affect the efficacy of dinoprostone in cervical ripening/labor duration? Clin Exp Obstet Gynecol. 2012;39(4):522-5.

19. Fusun Acarturk. Mucoadhesive Vaginal Drug Delivery Systems. Recent Patents on Drug Delivery \& Formulation. 2009;3:193-205.

Cite this article as: Kurian MJ, Rao B, Rao A, Shameem VPA. Effect of vaginal $\mathrm{pH}$ on efficacy of dinoprostone gel for labour induction. Int J Reprod Contracept Obstet Gynecol 2016;5:1196-1201. 